\title{
Natural amino acids as chiral auxiliaries in asymmetric Diels-Alder reactions
}

\author{
Maria P. Bueno, Carlos Cativiela, ${ }^{1}$ and José A. Mayoral \\ Departamento de Química Orgánica, Instituto de Ciencia de los Materiales de Aragón, \\ Universidad de Zaragoza, 50009 Zaragoza, Spain \\ Alberto Avenoza, Paula Charro, and Miguel A. Roy \\ Departamento de Química Orgánica, Colegio Universitario de la Rioja, Logroño, Spain \\ AND \\ JosÉ M. ANDRÉs \\ Instituto de Carboquímica, C.S.I.C., Zaragoza, Spain
}

Received June 10, 1988

\begin{abstract}
Maria P. Bueno, Carlos Cativiela, Jose A. Mayoral, Alberto Avenoza, Paula Charro, Miguel A. Roy, and Jose M. ANDRÉs. Can. J. Chem. 66, 2826 (1988).

To test whether $\alpha$-amino acids can be efficient chiral auxiliaries in asymmetric Diels-Alder reactions, the chiral dienophile $\mathrm{N}$-acryloyl-L-phenylalanine methyl ester was made to react with cyclopentadiene. Diastereofacial selectivity is to a great extent dependent on the Lewis acid used to promote the reaction; whereas moderate excesses of the $(1 R, 2 R)$-cycloadduct were achieved with $\mathrm{AlCl}_{3}$, the reaction did not show diastereofacial selectivity when titanium catalysts were used. Moreover, with $\mathrm{Ti}\left({ }^{\mathrm{i}} \mathrm{PrO}\right)_{4}$ a transesterification reaction, which leads to the isopropyl ester and competes with the Diels-Alder reaction, was observed. In spite of the structural similarity of this dienophile to the acrylate of $(S)$-ethyl lactate, it behaved very differently in the titanium-catalyzed reactions.
\end{abstract}

Maria P. Bueno, Carlos Cativiela, José A. Mayoral, Alberto Avenoza, Paula Charro, Miguel A. Roy et José M. ANDRÉs. Can. J. Chem. 66, 2826 (1988).

Afin de déterminer si les acides $\alpha$-aminés peuvent être des auxiliaires chiraux efficaces dans des réactions de Diels-Alder asymétriques, on a fait réagir le cyclopentadiène avec le diènophile chiral suivant: l'ester méthylique de la $N$-acryloyl-Lphénylalanine. La sélectivité diastéréofaciale dépend beaucoup de l'acide de Lewis utilisé pour promouvoir la réaction; alors que le $\mathrm{AlCl}_{3}$ nous permet d'obtenir de légers excès du cycloadduit- $(1 R, 2 R)$, on n'a pas détecté de sélectivité diastéréofaciale lorsqu'on a utilisé des catalyseurs de titane. De plus, avec le Ti(i-PrO) ${ }_{4}$, on a observé une réaction de transestérification qui entre en compétition avec la réaction de Diels-Alder et qui conduit à la formation de l'ester isopropylique. D'un point de vue structural, ce diènophile ressemble beaucoup à l'acrylate du $(S)$-lactate d'éthyle; malgré ces ressemblances, les deux se comportent très différemment au cours de réactions catalysées par le titane.

[Traduit par la revue]

High levels of diastereofacial selectivity have been achieved in asymmetric Diels-Alder additions of prochiral 1,3-dienes to dienophiles with a removable, chiral-directing auxiliary (1). However, it is interesting to test whether chiral reagents, both enantiomers of which are inexpensive and easily available, can be efficient chiral auxiliaries in this kind of reaction. In this context, reactions of acrylates (2) and fumarates (3) of several derivatives of chiral hydroxy acids with cyclopentadiene are reported to proceed with good selectivity, mainly when $\mathrm{TiCl}_{4}$ is used to promote the reaction. The results obtained are explained by the formation of a dienophile- $\mathrm{TiCl}_{4}$ chelate complex, which amplifies diastereofacial discrimination (4). Also several $N$ acryloyl and $N$-crotonyl compounds, such as the $N$-acyloxazolidones (5) and the $N$-acylsultams (6) derived from camphor, have been used as chiral dienophiles.

In spite of their availability, inexpensive natural $\alpha$-amino acids, which have been used in a lot of asymmetric reactions (7), have not been tested as chiral auxiliaries in asymmetric Diels-Alder reactions. In view of that, we have studied the reaction between cyclopentadiene and $N$-acryloyl-L-phenylalanine methyl ester (1).

The chiral dienophile was easily obtained by reaction of $\mathrm{L}$ phenylalanine with acryloyl chloride (8), followed by methylation with $\mathrm{BF}_{3}-\mathrm{MeOH}$ complex. $N$-acryloyl-L-phenylalanine methyl ester 1 was made to react with cyclopentadiene under several conditions, using a molar relationship dienophile: diene

\footnotetext{
'Author to whom correspondence may be addressed.

Printed in Canada / Imprimé au Canada
}

$=1: 6($ Scheme 1$)$. The results of the reactions were determined by hplc and are shown in Table 1 .

No significant solvent effect was found for the reaction of cyclopentadiene with dienophile $N$-acryloyl-L-phenylalanine methyl ester 1 , the slight changes in endo/exo selectivity conforming to the pattern found by Berson et al. (9) for reactions of acrylates with cyclopentadiene.

As expected, the use of $\mathrm{AlCl}_{3}$ as a catalyst caused a remarkable increase in both the reaction rate and endo/exo selectivity. When the reaction temperature was lowered the endo / exo ratio increased, but diastereofacial selectivity was not noticeably modified for reaction temperatures below $0^{\circ} \mathrm{C}$.

Helmchen and co-workers have previously reported $(2 a)$ that the use of $\mathrm{TiCl}_{4}$ to promote the reaction between cyclopentadiene and the acrylate of $(S)$-ethyl lactate causes a high diastereofacial differentiation, mainly with 0.75 equiv. of Lewis acid. In spite of the structural similarity between the dienophile used by these authors and $N$-acryloyl-L-phenylalanine methyl ester $\mathbf{1}$, in our case this catalyst gave low diastereofacial selectivity for all tested molar ratios of catalyst:dienophile.

To increase diastereofacial selectivity, a less effective titanium catalyst, $\mathrm{Ti}\left({ }^{\mathrm{i}} \mathrm{PrO}\right)_{4}$, was tested. The relationship between the areas of the hplc peaks corresponding to the endo products $\mathbf{2} a: \mathbf{2} b$ followed an unexpected pattern, since it increased with increasing reaction temperatures. A careful analysis showed that the peak corresponding to $2 a$ was contaminated by a new product, which was obtained by reaction of $N$-acryloyl-Lphenylalanine methyl ester with $\mathrm{Ti}\left({ }^{\mathrm{i}} \mathrm{PrO}\right)_{4}$ and identified as 
<smiles>C=CC(=O)Cl</smiles>

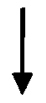<smiles>O=C(O)C=CC(=O)N[C@@H](Cc1ccccc1)C(=O)O</smiles>

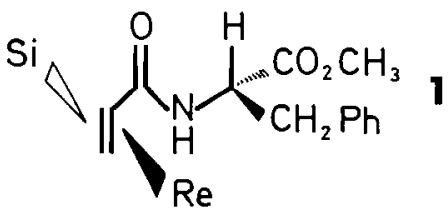

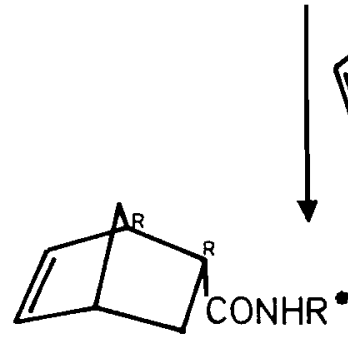

$2 a(1 \mathrm{R}, 2 \mathrm{R})$

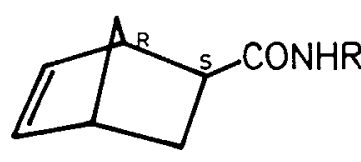

$3 a \quad(1 R .25)$
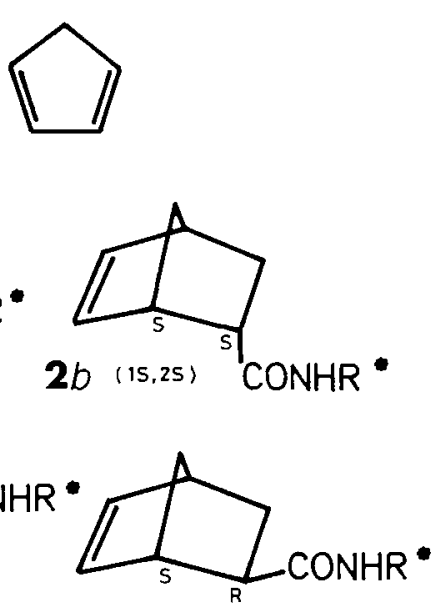

$3 b \quad(15,2 R)$

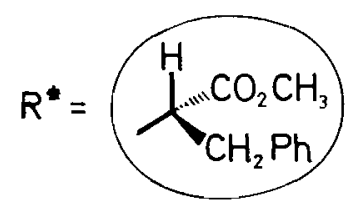

SCHEME 1

$\mathrm{N}$-acryloyl-L-phenylalanine isopropyl ester 4 . The proportion of this product increases with the reaction time and temperature (Scheme 2).

When the reaction was carried out at $-25^{\circ} \mathrm{C}$ the formation of the isopropyl ester $\mathbf{4}$ was minimized, and the ratio of $2 a: 2 b$ approached that obtained with $\mathrm{TiCl}_{4}$. Neither the Diels-Alder reaction nor ester formation occurred at still lower reaction temperatures.

$N$-Acryloyl-L-phenylalanine isopropyl ester 4 was made to react, in $\mathrm{CH}_{2} \mathrm{Cl}_{2}$ at $-40^{\circ} \mathrm{C}$, with 6 equiv. of cyclopentadiene using 1.1 equiv. of $\mathrm{AlCl}_{3}$ to promote the reaction. In comparison to the reaction between $N$-acryloyl-L-phenylalanine methyl

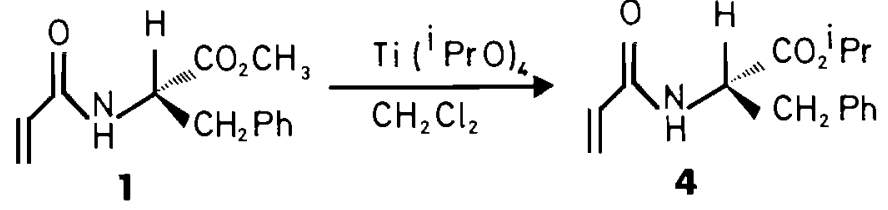

T $\left({ }^{\circ} \mathrm{C}\right) \quad$ Time $(\mathrm{h}) \quad$ Ratio $4: \mathbf{1}$

25

19

79

0

66

91

SCHEME 2

ester 1 and cyclopentadiene under the same conditions, a similar endo/ exo ratio (35.4:1) but a lower diastereofacial selectivity (54:46) were obtained.

The low diastereofacial selectivities obtained with titanium catalysts suggest that the coordination of $\mathbf{1}$ with this kind of catalyst does not lead to a chelate complex, similar to that postulated by Helmchen et al. for the acrylate of $(S)$-ethyl lactate - $\mathrm{TiCl}_{4}$ complex. However, the formation of $\mathrm{N}$-acryloyl-
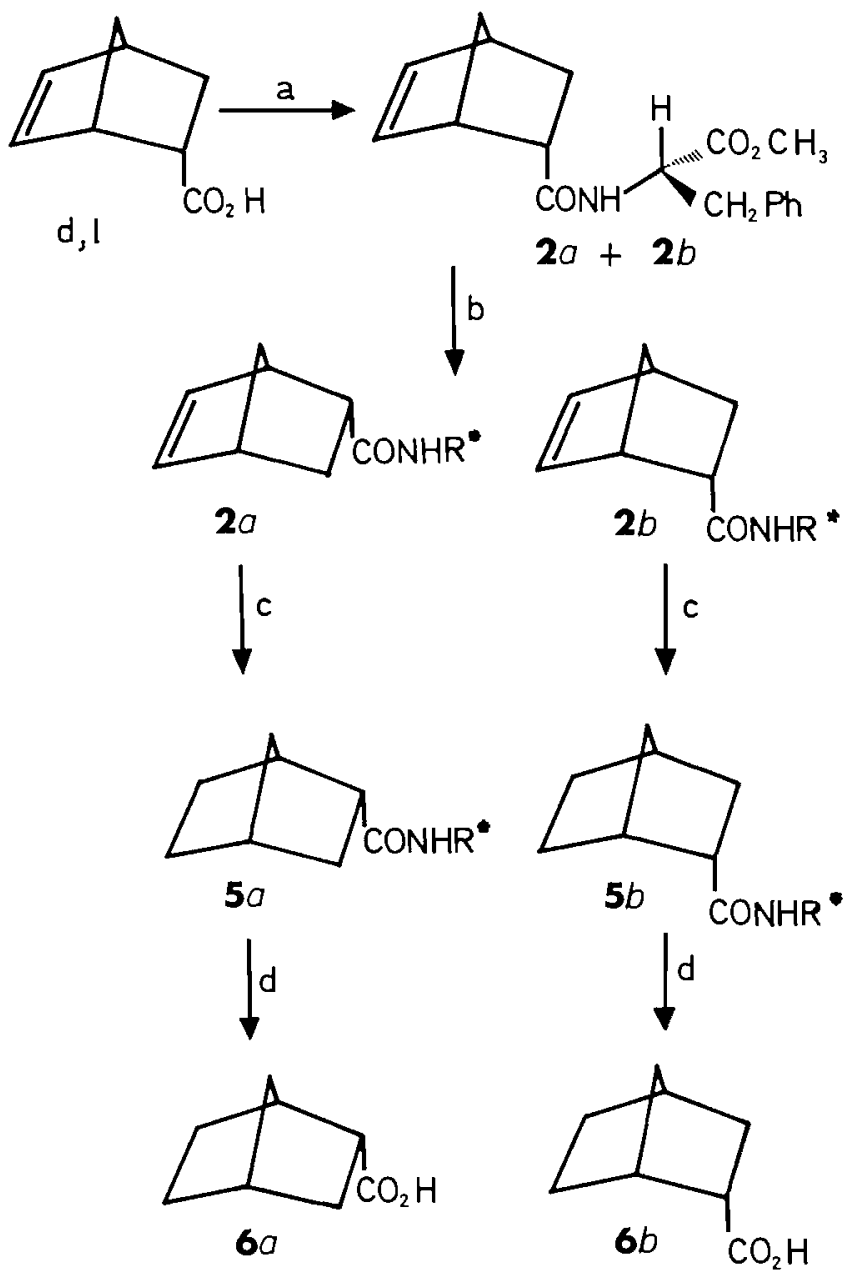

(a) $\mathrm{SOCl}_{2}$, followed by $\mathrm{L}_{-} \mathrm{H}_{2} \mathrm{NCH}\left(\mathrm{CO}_{2}^{-}\right) \mathrm{CH}_{2} \mathrm{Ph}$ and $\mathrm{BF}_{3} / \mathrm{MeOH}$ (b) Column Chromatography on Silica gel using $n$-Hexane $/ \mathrm{E}_{2} \mathrm{O}$ (1/3) as eluting agent : (c) $\mathrm{H}_{2}$, Pd/C: (d) $\mathrm{HCl} \mathrm{GN}$.

\section{SCHEME 3}


TABLE 1. Diels-Alder reactions of cyclopentadiene with $N$-acrylolyl-L-phenylalanine methyl ester (2)

\begin{tabular}{|c|c|c|c|c|c|c|}
\hline $\begin{array}{l}\text { Lewis acid } \\
\text { (equiv.) }\end{array}$ & Solvent ${ }^{a}$ & $T\left({ }^{\circ} \mathrm{C}\right)$ & Time (h) & Yield $(\%)^{b}$ & $\begin{array}{c}\text { endo / exo } \\
\text { ratio of } \\
2: 3^{b}\end{array}$ & $\begin{array}{l}\text { Ratio of } \\
2 a: 2 b^{b}\end{array}$ \\
\hline - & $\mathrm{CH}_{2} \mathrm{Cl}_{2}$ & 25 & 70 & 63 & $2.8: 1$ & $52: 48$ \\
\hline- & Toluene & 25 & 70 & 49 & $2.0: 1$ & $55: 45$ \\
\hline $\mathrm{AlCl}_{3}(1.1)$ & $\mathrm{CH}_{2} \mathrm{Cl}_{2}$. & 25 & 5 & 99 & $7.3: 1$ & $60: 40$ \\
\hline $\mathrm{AlCl}_{3}(1.1)$ & Toluene & 25 & 5 & 99 & $4.5: 1$ & $57: 43$ \\
\hline $\mathrm{AlCl}_{3}(1.1)$ & $\mathrm{CH}_{2} \mathrm{Cl}_{2}$ & 0 & 20 & 80 & $15.9: 1$ & $70: 30$ \\
\hline $\mathrm{AlCl}_{3}(1.1)$ & $\mathrm{CH}_{2} \mathrm{Cl}_{2}$ & -25 & 25 & 95 & $29.0: 1$ & $68: 32$ \\
\hline $\mathrm{AlCl}_{3}(1.1)$ & $\mathrm{CH}_{2} \mathrm{Cl}_{2}$ & -40 & 50 & 93 & $31.3: 1$ & $71: 29$ \\
\hline $\mathrm{AlCl}_{3}(1.1)$ & $\mathrm{CH}_{2} \mathrm{Cl}_{2}$ & -60 & 55 & 76 & $42.8: 1$ & $65: 35$ \\
\hline $\mathrm{TiCl}_{4}(0.75)$ & $\mathrm{CH}_{2} \mathrm{Cl}_{2}$ & 25 & 20 & 95 & $14.9: 1$ & $51: 49$ \\
\hline $\mathrm{TiCl}_{4}(0.75)$ & $\mathrm{CH}_{2} \mathrm{Cl}_{2}$ & -15 & 65 & 91 & $12.5: 1$ & $51: 49$ \\
\hline $\mathrm{TiCl}_{4}(1.1)$ & $\mathrm{CH}_{2} \mathrm{Cl}_{2}$ & -15 & 65 & 86 & $3.0: 1$ & $49: 51$ \\
\hline $\mathrm{TiCl}_{4}(1.7)$ & $\mathrm{CH}_{2} \mathrm{Cl}_{2}$ & -15 & 65 & 86 & $4.0: 1$ & $52: 48$ \\
\hline $\left.\mathrm{Ti}^{\mathrm{i}} \mathrm{PrO}\right)_{4}(1.1)$ & $\mathrm{CH}_{2} \mathrm{Cl}_{2}$ & -25 & 65 & 40 & $5.1: 1^{c}$ & $58: 42^{c}$ \\
\hline $\mathrm{Ti}\left({ }^{\mathrm{i}} \mathrm{PrO}\right)_{4}(1.1)$ & $\mathrm{CH}_{2} \mathrm{Cl}_{2}$ & -40 & 190 & - & - & - \\
\hline
\end{tabular}

${ }^{a}$ Twenty-five millilitres.

${ }^{b}$ Determined by hplc. Column, $5 \mu \mathrm{m}$ silica Hypersil ${ }^{\mathrm{R}}$. Eluent, ethanol-hexane, gradient 1 to $5 \%$ of ethanol in $1 \mathrm{~min}$. Flow rate, $2 \mathrm{~mL} / \mathrm{min}$. Detection, $215 \mathrm{~nm}, \epsilon_{1}: \epsilon_{2 a}: \epsilon_{2 b}: \epsilon_{3 a+3 b}=1.686: 1.034: 1.000: 1.030$.

'The peak corresponding to $2 a$ is contaminated by a small amount of $N$-acrylolyl-L-phenylalanine isopropyl ester 4 .

L-phenylalanine isopropyl ester 4 indicates that, in spite of the greater basicity of the amide moiety, there may be some degree of coordination to the ester moiety.

To determine the absolute configuration of the major product, endo- and exo-5-norbornen-2-carboxylic acids, which were prepared by reaction of acrylic acid with cyclopentadiene followed by iodolactone separation, were used to prepare endo and exo cycloadducts 2 and 3 . The endo mixture was separated into its components by means of column chromatography on silica gel, using $n-\mathrm{C}_{6} \mathrm{H}_{14} / \mathrm{Et}_{2} \mathrm{O}(1: 3)$ as eluting agent. By treatment of $2 a$ or $2 b$ with $20 \%$ aqueous $\mathrm{NaOH}$ only the ester moiety was hydrolysed and, after $2 \mathrm{~h}$, partial epimerization was observed. Treatment of $2 a$ and $2 b$ with aqueous mineral acids led to a complex mixture of products, probably due to Wagner-Meerwein type rearrangements (10). In view of this, $2 a$ and $2 b$ were hydrogenated and converted without epimerization into both enantiomers of the endo-norbornan-2-carboxylic acid, $6 a$ and $6 b$, by acid hydrolysis. The absolute configurations of these acids were determined by comparing their specific rotations with those given in the literature (11). Under these conditions $2 a$ gave $(1 S, 2 R, 4 R)$ norbornan-2-carboxylic acid and $2 b(1 R, 2 S, 4 S)$ norbornan-2-carboxylic acid, with optical

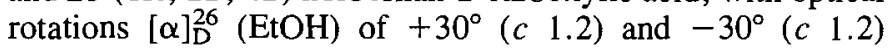
respectively (Scheme 3 ).

In all cases the Diels-Alder reaction led predominantly to the $(1 R, 2 R)$-endo diastereomer $2 a$, which comes from the attack of the cyclopentadiene on the Si face of the dienophile 1. This result can be explained on the basis of reactive conformer $\mathbf{1}$,

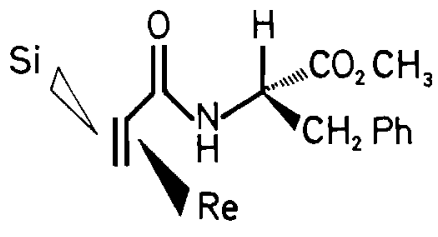

1

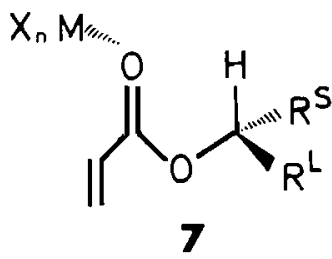

7 with antiplanar enoate conformation, which is similar to those postulated for complexes (7) of "classical" chiral acrylates with only one center capable of coordination (la) (Scheme 4). The preferential attack on the $S i$ face of the dienophile 1 suggests a possible electronic effect of the phenyl group (12).

\section{Experimental}

The ${ }^{1} \mathrm{H}$ nmr spectra were recorded at $80 \mathrm{MHz}$ with a Bruker model WP $80 \mathrm{CW}$ spectrometer and at $200 \mathrm{MHz}$ with a Varian model XL 200 spectrometer in $\mathrm{CDCl}_{3}$ with $\mathrm{Me}_{4} \mathrm{Si}$ as internal standard. High pressure liquid chromatography was performed using a Hewlett-Packard model 1090 M chromatograph; specific rotations were measured with a Perkin-Elmer model 241-MC polarimeter. Melting points were determined on a Buchi 510 apparatus and are uncorrected.

The chiral dienophile 1 was easily obtained by reaction of $\mathrm{L}$ phenylalanine with acryloyl chloride (8) followed by methylation with $\mathrm{BF}_{3}-\mathrm{MeOH}$ complex.

\section{A. Diels-Alder reactions \\ 1. Without a catalyst}

One millimole of 1 and $6 \mathrm{mmol}$ of cyclopentadiene were stirred under nitrogen in $25 \mathrm{~mL}$ of the appropriate solvent and at the temperature specified (Table 1). After the corresponding time the solvent was removed under reduced pressure and the residue was dissolved in methanol. The solution was filtered and evaporated under reduced pressure to give a solid, which was analyzed by hplc.

\section{With a catalyst}

One millimole of 1 and the corresponding amount of the catalyst were stirred in $20 \mathrm{~mL}$ of dry $\mathrm{CH}_{2} \mathrm{Cl}_{2}$ under nitrogen at the appropriate temperature for $1 \mathrm{~h}$. A solution of cyclopentadiene $(6 \mathrm{mmol})$ in $5 \mathrm{~mL}$ of dry $\mathrm{CH}_{2} \mathrm{Cl}_{2}$ at the same temperature was then added. The mixture was stirred for the adequate time (Table 1) and treated with a cold $10 \%$ aqueous $\mathrm{NaOH}$ solution in the case of $\mathrm{AlCl}_{3}$ or $15 \%$ aqueous $\mathrm{NaOH}$ solution in the case of titanium catalyst. The organic layer was dried with anhydrous sodium sulfate, filtered, and evaporated under reduced pressure to give a solid, which was analyzed by hplc.

B. Synthesis of $\mathrm{N}$-acryloyl-L-phenylalanine isopropyl ester 4

One millimole of 1 and $1.1 \mathrm{mmol}$ of $\left.\mathrm{Ti}^{(\mathrm{PrO}}\right)_{4}$ were stirred in $25 \mathrm{~mL}$ of dry $\mathrm{CH}_{2} \mathrm{Cl}_{2}$ under nitrogen at the appropriate temperature for the chosen time. The mixture was then treated with a $15 \% \mathrm{NaOH}$ solution and the organic layer was dried with anhydrous sodium sulfate, filtered, 
and evaporated under reduced pressure to give a solid, which was analyzed by hplc.

To obtain an analytically pure sample of 4 , the reaction was carried out with $2 \mathrm{mmol}$ of $\mathrm{Ti}\left({ }^{\mathrm{i}} \mathrm{PrO}\right)_{4}$ at room temperature for $72 \mathrm{~h}$, and the solid obtained after the treatment was recrystallized from diethyl ether $/ n$-hexane; $\mathrm{mp} 81-83^{\circ} \mathrm{C}$; nmr $\left(\mathrm{CDCl}_{3}\right) \delta: 1.12(\mathrm{~d}, 3 \mathrm{H}), 1.22(\mathrm{~d}$, $3 \mathrm{H}), 3.12(\mathrm{dd}, 2 \mathrm{H}), 4.9(\mathrm{~m}, 2 \mathrm{H}), 5.5(\mathrm{dd}, 1 \mathrm{H}), 6.1(\mathrm{~m}, 3 \mathrm{H}), 7.25(\mathrm{~m}$, $5 \mathrm{H}$ ). Anal. calcd. for $\mathrm{C}_{15} \mathrm{H}_{19} \mathrm{NO}_{3}: \mathrm{C} 68.94, \mathrm{H} 7.33, \mathrm{~N}$ 5.36; found: $\mathrm{C}$ $69.29, \mathrm{H} 7.07, \mathrm{~N} 5.43$.

\section{Alternative synthesis of methyl $-\mathrm{N}$-(endo-bicyclo [2.2.1] hept-2-car- bonyl)- $\mathrm{L}$-phenylalaninates $2 \mathrm{a}$ and $2 \mathrm{~b}$}

Ten millimoles of endo-bicyclo[2.2.1]hept-5-en-2-carboxylic acid and $15 \mathrm{mmol}$ of thionyl chloride in dry chloroform were refluxed for 3 h. After this time the solution was evaporated under reduced pressure and the residue was distilled at 14 Torr $(1$ Torr $=133.3 \mathrm{~Pa})$ to give $80 \%$ of the corresponding acyl chloride. This compound was dripped into a solution of $8 \mathrm{mmol}$ of L-phenylalanine in $10 \mathrm{~mL}$ of $10 \%$ aqueous sodium hydroxide previously cooled in an ice bath (if a precipitate appeared, a little more water was added). After $3 \mathrm{~h}$ the stirred solution was acidified with $6 \mathrm{~N}$ hydrochloric acid; the precipitate was filtered and recrystallized from water to give a $65 \%$ yield of $N$-(endobicyclo[2.2.1]hept-5-en-2-carbonyl)-L-phenylalanine. Five millimoles of this compound were refluxed with $\mathrm{BF}_{3}-\mathrm{MeOH}$ complex for $2 \mathrm{~h}$. The solution was washed with sodium acid carbonate solution and extracted several times with ether. The organic layer was separated and dried over anhydrous sodium sulfate. After removing the organic solvent a white oil appeared (yield $90 \%$ ), which was passed through a chromatographic column of silica gel, using $n$-hexane $/ \mathrm{Et}_{2} \mathrm{O}=1: 3$ as eluting agent, to give both diastereoisomers. These were recrystallized from $n$-hexane to give analytically pure samples of methyl- $N$ - (endobicyclo[2.2.1] hept-5-en-2-carbonyl)-L-phenylalaninate $2 a$ and $\mathbf{2 b}$. mp (2a) $114-116^{\circ} \mathrm{C}$; nmr $(2 a)\left(\mathrm{CDCl}_{3}\right) \delta: 1.23-1.40(\mathrm{~m}, 3 \mathrm{H}), 1.88(\mathrm{~m}$, lH), 2.82-2.89(m, 2H), 3.00-3.20 (m, 3H), $3.73(\mathrm{~s}, 3 \mathrm{H}), 4.85(\mathrm{~m}$, $1 \mathrm{H}), 5.74(\mathrm{~m}, 1 \mathrm{H}), 6.18(\mathrm{~m}, 1 \mathrm{H}), 7.08-7.32(\mathrm{~m}, 5 \mathrm{H})$. Anal. calcd. for $\mathrm{C}_{18} \mathrm{H}_{21} \mathrm{NO}_{3}: \mathrm{C} 72.22, \mathrm{H} 7.07, \mathrm{~N} 4.68$; found: C 71.96, H 7.20, N 4.93 . For $2 b: \mathrm{mp} 80-82^{\circ} \mathrm{C}$; $\mathrm{nmr}\left(\mathrm{CDCl}_{3}\right) \delta: 1.24-1.45(\mathrm{~m}, 3 \mathrm{H}), 1.92(\mathrm{~m}$, lH), $2.81-2.90(\mathrm{~m}, 2 \mathrm{H}), 3.00-3.20(\mathrm{~m}, 3 \mathrm{H}), 3.73(\mathrm{~s}, 3 \mathrm{H}), 4.83(\mathrm{~m}$, $1 \mathrm{H}), 5.85(\mathrm{~m}, 1 \mathrm{H}), 6.18(\mathrm{~m}, 1 \mathrm{H}), 7.06-7.38(\mathrm{~m}, 5 \mathrm{H})$. Anal. found: $\mathrm{C}$ $72.52, \mathrm{H} \mathrm{7.33,N} 4.21$.

Two millimoles each of $2 a$ and $2 b$ in $20 \mathrm{~mL}$ of methanol were hydrogenated at room temperature and atmospheric pressure using $10 \% \mathrm{Pd} / \mathrm{C}$ as catalyst until completion of the reaction (tlc). In $1 \mathrm{~h}$ the hydrogenation was completed, the catalyst filtered off, and the solvent removed under reduced pressure to give white solids, $\mathbf{5} a$ and $\mathbf{5} b$, in quantitative yield. Anal. calcd. for $\mathrm{C}_{18} \mathrm{H}_{23} \mathrm{NO}_{3}: \mathrm{C} 71.73, \mathrm{H} 7.69, \mathrm{~N}$ 4.65; found for $5 a$ : C 71.54, H 7.99, N 4.15; found for $5 b$ : C 71.45, H $7.96, \mathrm{~N} 4.28$

To identify the major product in the Diels-Alder reaction, 1 millimole each of $5 a$ and $5 b$ in $5 \mathrm{~mL}$ of $6 \mathrm{~N}$ hydrochloric acid were refluxed for $24 \mathrm{~h}$. After this time the solution was extracted with ether and the organic layer was dried over anhydrous sodium sulfate and evaporated to give both endo bicyclo[2.2.1] heptan-2-carboxylic acids $6 a$ and $6 b$ whose specific rotations were measured, $[\alpha]_{\mathrm{D}}^{26}(6 a)+30^{\circ}(c$ 1.2 , EtOH $)$ and $[\alpha]_{\mathrm{D}}^{26}(6 b)-30^{\circ}(c 1.2, \mathrm{EtOH})$, and compared with the literature value, $[\alpha]_{\mathrm{D}} 30.6^{\circ}(c 1.2, \mathrm{EtOH})(11)$.

\section{Acknowledgements}

This research was made possible by the generous financial support of the Comisión Asesora de Investigación Científica y Técnica (project number PB85-0335). María P. Bueno would like to express her gratitude to the Diputación General de Aragón and Paula Charro to the Instituto de Estudios Riojanos for a grant.

1. (a) W. OPPOLzer. Angew. Chem. Int. Ed. Engl. 23, 876 (1984); (b) Tetrahedron, 43, 1969 (1987); (c) L. A. PaquetTe. In Asymmetric synthesis. Vol. 3. Edited by J. D. Morrison: Academic Press, New York. 1984.

2. (a) T. Poll, G. Helmchen, and B. Bauer. Tetrahedron Lett. 25, 2191 (1984); (b) T. Poll, A. SobCzaK, H. Hartmann, and G. HeLMCHEN. Tetrahedron Lett. 26, 3095 (1985).

3. H. HaRtmann, A. F. A. Hady, K. Sartor, J. WeEtman, and G. HelmCheN. Angew. Chem. Int. Ed. Engl. 26, 1143 (1987).

4. T. Poll, J. O. Metter, and G. Helmchen. Angew. Chem. Int. Ed. Engl. 24, 112 (1985).

5. D. A. Evans, K. T. Chapman, and J. Bisaha. J. Am. Chem. Soc. 106, 4261 (1984).

6. W. Oppolzer, C. Chapuis, and G. Bernardinelli. Helv. Chim. Acta, 67, 1397 (1984).

7. (a) K. Drauz, A. Kleeman, and J. Martens. Angew. Chem. Int. Ed. Engl. 21, 584 (1982); (b) G. M. Coppola and H. F. SCHUSTER. Asymmetric synthesis. John Wiley and Sons, New York. 1987.

8. R. K. Kulkarni and H. Morawetz. J. Polym. Sci. 54, 491 (1961).

9. J. A. Berson, Z. Hamlet, and W. A. Mueller. J. Am. Chem. Soc. 84, 297 (1962).

10. M. Nakazaki, K. Naemura, and H. Kadowaki. J. Org. Chem. 43, 4947 (1978).

11. (a) J. A. Berson and D. A. Ben-EFraim. J. Am. Chem. Soc. 81, 4083 (1959); (b) J. A. Berson, J. S. Walia, A. Remanick, S. SuzukI, P. ReYNOLdS-WARNHOFF, and D. WillNer. J. Am. Chem. Soc. 83, 3986 (1961).

12. D. A. Evans, K. T. Chapman, D. Tan Hung, and A. T. Kawaguchi. Angew. Chem. Int. Ed. Engl. 26, 1184 (1987). 


\section{This article has been cited by:}

1. Paul F. Vogt, Marvin J. Miller. 1998. Development and applications of amino acid-derived chiral acylnitroso hetero DielsAlder reactions. Tetrahedron 54:8, 1317-1348. [CrossRef]

2. Alberto Avenoza, Carlos Cativiela, Miguel París, Jesús M. Peregrina. 1996. The use of 1-amino-2-phenyl-1cyclohexanecarboxylic acids as chiral auxiliaries in asymmetric Diels-Alder reactions. Tetrahedron 52:13, 4839. [CrossRef]

3. Stefano C.G Biagini, Stephen M Bush, Vernon C Gibson, Luisa Mazzariol, Michael North, William G Teasdale, Carol M Williams, Guiseppe Zagotto, Dora Zamuner. 1995. The synthesis of N-norbornenyl-amino acids and esters: Monomers for the preparation of well defined polymers. Tetrahedron 51:26, 7247-7262. [CrossRef]

4. Walder Adam, Victor Oswaldo Nava Salgado, Eva-Maria Peters, Karl Peters, Hans Georg Von Schnering. 1993. Stereoselective Synthesis of \#,\#-trans1-Spiro-\#1-lactones by Diels-Alder Cycloaddition of 1,3-Dienes to \#1-Methylene\#1-lactone and Their Decarboxylation by Pyrolysis to (E)1-Alkylidenecycloalkenes, a Convenient Olefination Method. Chemische Berichte 126:6, 1481-1486. [CrossRef]

5. A. Avenoza, María P. Bueno, Carlos Cativiela, José A. Mayoral. 1992. Asymmetric synthesis of exo-norbornane-2-carboxylic acids. Tetrahedron: Asymmetry 3:3, 343-346. [CrossRef]

6. Francisco Torrens, Manuel Ruiz-López, Carlos Cativiela, José I. García, José A. Mayoral. 1992. Conformational aspects of some asymmetric Diels-Alder reactions. A molecular mechanics + polarization study. Tetrahedron 48:24, 5209-5218. [CrossRef]

7. Herbert Waldmann. 1990. Aminosäureester als chirale Hilfsgruppen in Lewis-Säure-katalysierten Diels-Alder-Reaktionen. Liebigs Annalen der Chemie 1990:7, 671-680. [CrossRef]

8. H Waldmann. 1989. On the enhancement of stereoselection by cooperation between chiral auxiliaries. Asymmetric dielsalder reactions with fumaric acid bis ((S)-proline benzyl ester) amide. Tetrahedron Letters 30:32, 4227-4230. [CrossRef] 